\title{
The Uses of Irony and the Carnivalesque in Leigh Hobbs' Picture Books
}

\author{
Nicole Humphrey
}

A s an author-illustrator Leigh Hobbs has produced six books; five of these are about Old Tom, and the sixth is Horrible Harriet. Nodelman (1988, p.223) claims that ' $[\mathrm{w}]$ hen words and pictures combine, irony emerges from the way in which the incompleteness of each is revealed by the differing incompleteness of the other'. The disparity between the text and the illustrations and the different points of view offered in Hobbs' texts exemplify this irony. In addition, the characters and plots of his stories feature carnivalesque motifs where the prevailing social order is subverted. Bakhtin (1994, p.204) refers to the 'material bodily principle' as a key feature of carnivalesque. This manifests itself as an emphasis on food and dirt in Hobbs' stories. The characterization of Angela and Old Tom reflect the dual role of the carnivalesque to celebrate the joy of life, whilst undermining or degrading notions of high ideals.

The Old Tom stories pivot on the conflict between Angela Throgmorton (the authority figure) and Old Tom. Angela is house-proud and is often seen wearing an apron and cleaning. By contrast, Old Tom is seen surrounded by mess. Their names are suggestive of their oppositional roles. Angela is the angel of the home, providing a safe and secure environment for Old Tom. His name is reminiscent of 'Old Nick', and his horn-like ears and devilish grin imply he is up to no good. The texts highlight the conflict between Angela's controlled and ordered world, and the playful anarchy of Old Tom's, and the resolution of the stories always suggest a compromise between the two. Old Tom is forced to abide by Angela's authority, while she is forced to accept his laziness and mess. The resolution of the narratives suggest that despite the conflict, Angela and Old Tom love and need each other. She provides the stability in their relationship, while he provides the spontaneity.

The dichotomy in the characterization of Old Tom and Angela is gender biased. She conforms to a stereotypical view of the feminine, firmly confined within a role of housewifely duties: cooking, cleaning and modifying Old Tom's manners and behaviour. This emphasis on housework means that she is not free to have the adventures that Old Tom has. When accidentally propelled into space on the rocket because 'she spied a spot she hadn't scrubbed' and frantically started cleaning as the rocket took off, the accompanying text states, 'Angela was angry. She had work to do at home.'(Hobbs 1994). The home is Angela's sphere of influence and power and she is active there. This contrasts with Old Tom's general avoidance of work, with images of him loafing on a sofa or in bed. However, outside the home, Angela is seen as passive, illustrated in their trip to the beach, where she spends the whole time sleeping on the sand (Hobbs 1995). Old Tom, in contrast, displays the traditional masculine characteristics of action and adventure.

The third person narrative used in the texts is an essential strategy of Hobbs' comic purpose, giving the reader access to both Angela's and Old Tom's feelings because we view them from outside the story. Perry Nodelman (1988, p.225) has noted that certain narrative positions, when combined with illustrations, make the narrator 'into a character with narrative significance...He is a character exclusive to the text but revealed by the pictures.'. This is the case with the narrator of Hobbs'stories. The tone of voice used is matter of fact, suggesting a neutral observation of the characters and situations; the pictures, however, highlight the obvious half-truth and understatement of the words, and endow them with meanings other than the simply literal.

An example of the disparity between what the words say and what the pictures show can be seen in the opening sentence of Old Tom (Hobbs 1994). The emphatic tone of 'Angela Throgmorton lived alone and liked it that way' is undermined by her frown and the keenness with which she adopts Old Tom. Despite the words, the impression given is that Angela is lonely and does not really like living alone. The disparity between the text and pictures is also used for comic effect in Old Tom's Guide to Being Good (Hobbs 1998). The narrator's statement, 'Luckily Old Tom's good looks hadn't gone to his head' is accompanied by pictures of Old Tom preening and puckering as he stares at his own reflection. This provides two reasons for amusement. The pictures show us that Old Tom is indulging in vanity, despite the narrator's claim, and that both the narrator and Old Tom apparently share a mistaken belief in the existence of Old Tom's 'good looks'. The way in which the narrator presents Old Tom's point of view serves to position the reader to share it as well. The illustrations, however, offer alternative points of view and 
provide the reader with a different position from which to make meaning of the narrative.

Nodelman observes that 'a subtle sort of irony occurs when the tone of the words in a picture book does not seem to match the situation the pictures show us.' (1988, p.226). This can be seen in Old Tom's 'essential Mars survival kit' (Hobbs 1997), containing amongst its items a tennis racket, toy train and pirate hat whose 'essential' nature is doubtful. Hobbs uses this strategy in Horrible Harriet (Hobbs 2001) as well. There is a delightful drawing of Harriet snatching Athol's lunch, using a mechanised hand, although the accompanying text says he lost his lunch. On the penultimate page the text states, 'Her old friends had been neglected' with a picture of Harriet grinning evilly at her classmates, vampire fangs in place. The irony resides in the choice of language used. We know that she has no friends and that the neglect referred to is the fact that she has not been terrorising her classmates recently.

Nodelman explains that

In showing more than the words tell us, the pictures not only tell their own story; they also imply an ironic comment on the words. They make the words comic by making them outrageously incomplete, only a half-truth, and by making their incompleteness so obvious.

(1988, p224)

This occurs in Old Tom's Holiday (Hobbs 2002), where Angela and the narrator are unaware of Old Tom's presence on the holiday. Even when Angela sees Old Tom she refuses to believe her eyes, thinking he must be a mirage.

Stephens has noted (1992, p.122) that carnival 'discourse is often idiomatic, and rich in a play of signifiers which foregrounds the relativity of sign-thing relationships, and hence the relativity of prevailing "truths" and ideologies.' The discourse used by Hobbs is linguistically playful. In Old Tom (Hobbs 1994), Angela believes she has found a baby monster. Old Tom is never referred to as a cat, but is constructed as either a baby (by Angela when going to rescue him) or a monster (by cinema patrons and the newsreader). Linguistic play is apparent also in Old Tom Goes to Mars (1997), when Angela buys Old Tom, her 'big baby', a 'playhouse'. Both Old Tom and the reader are aware that it is a rocket, although it is never referred to as such.

Old Tom stares hypnotically out from the covers of his books, making direct eye contact with the reader. His toothy grin is engaging, and his stance passive and nonthreatening. In the background we can see Angela gazing at Old Tom with obvious disapproval. The reader is being invited to share Old Tom's adventures and ignore Angela's socialising presence, just as Old Tom does. Even on the cover of Old Tom Goes to Mars, where the reader has a view of Old Tom's back as he looks through his telescope at the night sky, readers are positioned to share his view of the infinite possibilities offered by it, and the destination of Mars suggested in the title. We are similarly invited into Horrible Harriet's adventure. Her big smile and her wide-open arms and window attract us to her, simultaneously suggesting that the title epithet of 'horrible' may be misplaced.

The reader is positioned to share Old Tom's point of view, sharing his position over that of Angela, delighting in the anarchy and hedonism seen in the exuberance of his play. Despite being a cat, Old Tom stands on two legs, sleeps tucked in a bed, and is taught to use a knife and fork. Angela treats him as her baby, and he certainly has a childlike enjoyment of play. His anthropomorphism makes his anarchy more acceptable to the implied reader. As John Stephens has noted (1992, p.134) the audience can empathise with the human emotions of the character, while being distanced from his animality and his behaviour seems amusing rather than threatening. He is not a human and therefore is not expected to behave like one. The irony of this is that although the reader may not expect human behaviour from him, Angela certainly does. She reprimands him for eating the pet fish out of the fish bowl: 'Aren't you a little too old for such things?', expecting him to outgrow this behaviour like his other 'childish pranks' (Hobbs 1994).

Horrible Harriet's behaviour does not meet society's expectations for a girl. Harriet assumes power and authority. She has the teachers locked in the cellar and is in control of the playground. She is also able to manipulate Mr Boggle through play-acting socially acceptable behaviour. She has moments of animality seen in her chicken suit, vampire fangs, and even her nest, which amuses but also distances the reader from Harriet's behaviour in the same way that 
Old Tom's animality creates distance. Despite facing the reader in most pages, she never makes eye contact, always looking askance. Her size and brightly coloured clothes focus our attention, but it is impossible to ignore the unhappy children or the terrified Mr Scruffy, who although diminutive and drab in comparison to Harriet, offer alternative points-of-view and highlight her cruelty. John Stephens believes the complexity of the reader's response to such characters is typical of interrogative texts like this one:

...readers' attitudes to the main character, for example, and to the ways in which that character relates with the world of the text and its events, may shift amongst such positions as empathy, delight, superiority, criticism, outrage, revulsion, and so on, and may even combine two or more in one response.

(Stephens 1992, p.124)

The disparity between Hobbs' line drawings, with an emphasis on facial expression, and the discourse of the texts, work to convey a multiplicity of meanings. Old Tom is usually positioned in the foreground of the illustration and our focus of attention is on him, especially as he often makes eye contact with the reader. In Old Tom, he has been enjoying a life of mayhem and leisure, and has been oblivious of the depths of Angela's despair. Readers, however, have not. We've seen Angela watching Old Tom's antics with distaste, and know of her hay fever, insomnia, and shattered nerves. This has provided us with an alternative view of Old Tom's behaviour, and an awareness of his self-indulgence, in much the same way as the children and Mr Scruffy in Horrible Harriet offer us different points of view. 'As William Moebius says, an illustrator can "represent points of view other than those of the main character...by depicting tacit witnesses on the fringes or in the foreground or background of the picture", (Nodelman 1988, p.235).

Angela is shown firmly placing Old Tom on the other side of the page. She is boldly outlined and her presence is further emphasised by her black dress and larger size. Old Tom turns his face not towards Angela, but towards the reader and he gazes out with a forlorn, beseeching expression, appealing to us. Angela, however, is determined and on the next page kicks him out. The text is emphatic- "It was a bold move, but Angela thought it for the best'- but the illustration undermines this idea, as Angela pensively stares out into the street (Hobbs 1994). We see Old Tom's back as he goes off alone into the world, represented by the city in front of him.

After being kicked out of home by Angela, Old Tom is able to freely indulge in his antics without threat of reprimand. He enjoys himself, wandering at will. The movement away from his normal setting, and freedom from Angela's socialising presence demonstrate key features of the carnivalesque. Bakhtin claims that the "carnival celebrated temporary liberation from the prevailing truth and from the established order; it marked the suspension of all hierarchical rank, privileges, norms, and prohibitions' (1994, p.199). In children's literature this aspect of the carnival "offer[s] the characters "time out" from the habitual constraints of society but incorporate[s] a safe return to social normality' (Stephens 1992, p.121). So although Old Tom is free to do as he pleases, people and animals flee from him in horror, and finally the crowd unites to banish him from Happyland. He has no one who loves him and his isolation is obvious. The violence of the storm is emphasised by many lines and crosshatching, and Old Tom's terror can be seen in his open-mouthed scream, fur standing on end. Old Tom '[dreams] of his warm safe bed' while he scavenges scraps from the bin. He longs for home, with both its security and prohibition. His subsequent capture by the pound, and Angela's rescue of him, creates a harmonious ending; hand-in-hand they walk off into the sunset, like mother and child.

Bakhtin identifies the 'material bodily principle' as a key feature of carnivalesque texts, where 'images of the human body with its food, drink, defecation, and sexual life, plays a predominant role' (1994, p.204). John Stephens claims that the latter two concerns are 'usually displaced into opportunities for getting dirty' and 'into questions of undress' in children's literature (Stephens 1992, p.122). Leigh Hobbs's texts clearly demonstrate these features.

The banquet is an important aspect of carnivalesque and represents a joyful devouring of the world.

In the act of eating...the confines between the 
body and the world are overstepped by the body; it triumphs over the world, over its enemy, celebrates its victory, grows at the world's expense. This element of victory and triumph is inherent in all banquet images...It is the triumph of life over death.

(Bakhtin 1994, p.229)

Old Tom's joyful and exuberant gluttony depicts this function of the banquet. We see him indulging in whole chickens, ice cream cones topped with fifteen scoops, and the leg of a guest at the Queen's afternoon tea party. He fantasises about being made King of the Martians, where he can eat anything he wants. The accompanying picture shows him blown up like a balloon, spread over two pages and squashing the Martians flat. The images of abundance here are festive and demonstrate hyperbolic grotesque in the exaggerated size of the food and Old Tom as he expands.

Grotesque realism is also to be found in the images of food in Horrible Harriet. The tentacled creatures cooking in her pot, as well as the 'monster tail' and 'bat ear' used as ingredients, are offal. These images have the same significance that Bakhtin places on tripe. 'Tripe, stomach, intestines are the bowels, the belly, the very life of man. But at the same time they represent the swallowing, devouring body' (1994, p.215). This ambivalence is characteristic of the 'material bodily principle' with an emphasis on 'degradation, that is the lowering of all that is high, spiritual, ideal, [and] abstract' (Bakhtin 1994, p.205).

In Old Tom at the Beach Angela makes Old Tom a pair of board shorts, which he loses in a very comic scene. On the left side of the page Angela's prostrate form is seen relaxing on the beach. This is contrasted with Old Tom's look of panic, arms raised and the text 'Suddenly...' on the opposite page. Old Tom is apparently in danger; however, when we turn the page, we realise that the 'nibble down below' is focused not on him but on his shorts. The smiling fish disappears with the shorts firmly clasped in its teeth. Angela has attempted to restrict Old Tom by clothing him. His state of undress is a celebration of freedom from both Angela's and society's expectations.

The degradation and baseness that is an intrinsic part of carnivalesque manifests itself in defecation and dirt. Old Tom is messy and opportunities for getting dirty abound in the texts. His room is always in a state of disarray, and fleas often accompany him. At the beach he digs for treasure, and surrounds himself with a pile of discovered rubbish. This contrasts with Angela's preoccupation with housework and cleanliness, as she attempts to impose limitations on Old Tom's opportunities to revel in squalor and filth.

Role-playing is an important aspect of carnivalesque texts because it epitomises the suspension and liberation from the normal social order. Old Tom dreams he is King of the Martians, a land of freakish beings without the requisite number of eyes. His fantasy is broken when 'a Martian [speaks]', accompanied by a picture of Angela (Hobbs 1997). This aligns her with the misfits from Mars, and suggests that Old Tom doesn't need to leave home, as he is already King of the Martians. Another example of his role-playing occurs with his adventures with the pirates. When first hooked by the pirates Old Tom looks terrified. They are rough and mean looking; however, 'the pirates soon made him feel welcome'(Hobbs 1995.) He is kitted out like them and throws himself into the party atmosphere. The pirates share his chaotic and pleasure-loving attitude to life. Hobbs highlights this ironically when Percy Pirate puts a whole chicken in his mouth, and Old Tom's face shows embarrassed surprise. The accompanying text reiterates Angela's values: 'during the party, Percy the Pirate forgot his manners' (Hobbs 1995).

Horrible Harriet displays a different form of carnivalesque, which 'consists of books that are endemically subversive of such things as social authority, received paradigms of behaviour and morality, and major literary genres associated with children's literature' (Stephens 1992, p.121). Harriet is not a nice character. She is 'mean and nasty, cruel and wicked' (Hobbs 2001), but she holds the balance of power. The bully is privileged, in contrast to most children's stories where good triumphs over evil. Through her friendship with Athol, Harriet changes, a change that suggests that she has behaved anti-socially because she has never had a friend. Ironically, her friendship with Athol is only possible because he misinterprets her behaviour towards him, not realising that she is being horrible. With Athol's departure, Harriet returns to her bullying and Athol's socialisation has 
no lasting affect on her.

Using irony and carnivalesque features, Leigh Hobbs has created characters and situations that are subversive and humorous. The contradictions between his text and illustrations are used to comic effect. Carnivalesque features such as the 'material bodily principle', grotesque realism, and role-playing, are used to invert the social norms. Both Old Tom and Harriet are privileged during this inversion, offering a joyful triumph and expression of life.

\section{REFERENCES}

Bakhtin, Mikhail (1994) 'Carnival ambivalence', in Pam Morris (ed) The Bakhtin Reader: Selected Writings of Bakhtin, Medvedev, Volishinov, trans Helene Iswolsky, London, Arnold, pp.194-244.

Hobbs, Leigh (1994) Old Tom, Camberwell, Vic, Puffin.

Hobbs, Leigh (1995) Old Tom at the Beach, Camberwell, Vic, Puffin.

Hobbs, Leigh (1997) Old Tom Goes to Mars, Camberwell, Vic, Puffin.
Hobbs, Leigh (1998) Old Tom's Guide to Being Good, Camberwell, Vic, Puffin.

Hobbs, Leigh (2001) Horrible Harriet, Crows Nest, NSW, Allen and Unwin.

Hobbs, Leigh (2002) Old Tom's Holiday, Sydney, ABC Books.

Nodelman, Perry (1988) 'Irony in picture books: subjectivity and objectivity, time and space', in Words About Pictures: The Narrative Art of Children's Picture Books, Athens, Georgia, University of Georgia Press.

Stephens, John (1992) 'Ideology, carnival and interrogative texts', in Language and Ideology in Children's Fiction, London, Longman, pp.120-157.

\section{BIOGRAPHICAL NOTE}

Nicole Humphrey is the teacher-librarian at Cambridge Primary School in Hoppers Crossing, Melbourne. She is currently studying towards an MA (Children's Literature) at Deakin University, which she will complete at the end of this year. 